\title{
Karakteristik Kecepatan Aliran Di Dekat Dasar Pintu Peluapan Bawah (Sluice Gate)
}

\author{
Characteristic of Flow Velocity at the Bottom of Under Sluice Gate
}

\author{
Agatha Padma Laksitaningtyas $^{1 *}$, Djoko Legono ${ }^{1}$, Bambang Yulistiyanto ${ }^{1}$ \\ ${ }^{1}$ Departemen Teknik Sipil dan Lingkungan, Fakultas Teknik, Universitas Gadjah Mada, Yogyakarta, \\ Indonesia
}

\section{Article info:}

Kata kunci:

aliran bebas, aliran terendam, pintu air, vena kontrakta

Keywords:

free flow, sluice gate, submerged flow, vena contracta

Article history:

Received: 16-01-2020

Accepted: 28-05-2020

*)Koresponden email:

agathapadma@mail.ugm.co.id

\begin{abstract}
Abstrak
Pintu air berfungsi sebagai pengatur aliran air yang berfungsi untuk mengendalikan debit, muka air dan monitoring debit. Aliran air yang mengalir melalui pintu dapat dalam kondisi aliran bebas maupun aliran terendam yang tergantung dari kedalaman tailwater. Karakteristik aliran yang mengalir melalui pintu air berdasarkan persamaan keseimbangan energi dan momentum, yang tergantung dari tekanan, kecepatan dan kedalaman air yang berada di hulu /hilir pintu air. Hidrolika pintu air terutama pada kondisi aliran bebas sangat dinamis, termasuk profil muka air, gaya yang terjadi pada pintu, atau distribusi pintu bagian bawah, yang banyak diabaikan. Terdapat beberapa pengembangan rumus dasar dari aliran yang mengalir melalui pintu air, terutama pada pengembangan vena kontrakta. Vena kontrakta akan menghasilkan nilai dari koefisein debit $\left(C_{d}\right)$ dan koefisien kontraksi $\left(C_{c}\right)$ yang didapatkan dari rasio perhitungan metode yang sudah ada. Metode dapat juga dengan rasio pengukuran, perhitungan kejadian secara teoritis dan melalui percobaan di laboratorium. Persamaan debit melalui pintu tidak terlalu efektif bila digunakan pada kondisi bukaan pintu yang besar dan pada kondisi pintu terendam penuh.
\end{abstract}

Abstract
The sluice gate functions as a regulator of water flow to control
discharge, water level and for monitoring the discharge. Water
flowing through the sluice gate can be in a free flow condition or in
a submerged flow condition that depends on depth of tailwater. The
flow characteristics flowing through the sluice are based on the
equation of energy and momentum conservation law, which
depends on the pressure, velocity and depth of water that is
upstream/downstream of the sluice. Hydraulics of sluice especially
in free-flow conditions is very dynamic, including the profile of
water level, the force that occurs on the sluice gate, or the velocity
distribution of the bottom sluice gate, which is largely ignored.
There are several basic development formulas of flows through the
floodgates, especially in the development of vena contracta. Vena
contracta will produce the values of the coefficient of discharge
$(C d)$ and the coefficient of contraction ( $C c$ ) obtained from the
calculation ratio of existing methods. Calculation of events
theoretically and through experiments in the laboratory. However,
the equation of discharge through the sluice gate is not very
effective when used in a large opening condition and in a fully
submerged condition.

Kutipan: Padma Laksitaningtyas, A., Legono, D., \& Yulistiyanto, B. (2020). Karakteristik Kecepatan Aliran Di Dekat Dasar Pintu Peluapan Bawah (Sluice Gate). Jurnal Teknik Pengairan. https://doi.org/10.21776/ub.pengairan.2020.011.01.07 


\section{Pendahuluan}

Pintu air merupakan pintu yang dapat terbuka dan tertutup pada bagian bawah secara vertikal, dimana zat cair dapat mengalir melalui lubang tersebut. Pergerakan vertikal dari bukaan pintu mengontrol pembukaan pintu dan aliran akan mengalir dari hulu masuk ke lubang kemudian ke bagian hilir pintu. Pintu air ini dapat digunakan untuk mengendalikan dan mengukur aliran air bagian hulu air atau permukaan air hilir (Silva and Rijo 2017). Pintu air merupakan bangunan berupa lubang atau bukaan pada struktur hidraulika yang berfungsi untuk mengendalikan debit dan mengendalikan elevasi muka air di bagian hulu, dan dapat difungsikan sebagai alat pengukur aliran. Pintu air dengan lebar saluran berbentuk persegi dengan lebar $B$, yang merupakan struktur pada saluran terbuka yang paling umum pada rekayasa hidraulika dan sering dipelajari untuk prediksi menentukan karakteristik aliran dibawah pintu. Pada saat bukaan pintu air besar, kehilangan energi pada yang melalui pintu kecil dan aliran air yang besar akan menjadi aliran terendam. Kondisi tersebut menyebabkan penyimpangan yang besar antara model dan pengukuran debit. Salah satu alasan yang membuat penelitian mengenai pintu air adalah ketidakpastian yang besar pada perbedaan pengukuran elevasi muka air pada hulu dan hilir pintu air, tetapi variabel koefisien kontraksi yang akan berperan. Variasi koefisien kontraksi dengan relatif bukaan pintu dan relatif terendam terutama pada bukaan pintu yang lebar, hampir sama dengan koefisien kontraksi pada aliran terendam dan aliran bebas pada bukaan pintu yang kecil (Gilles Belaud, Cassan, and Baume 2009).

Ketika pintu air dibuka besar, kehilangan energi yang terjadi pada pintu air kecil dan aliran yang terjadi sebagian terendam. Kondisi tersebut menyebabkan penyimpangan yang besar antara model dan pengukuran debit. Ketidakpastian dalam pengukuran yaitu adanya perbedaan antara elevasi muka air di hulu dan hilir pintu air, tetapi variabel koefisien kontraksi $\left(C_{c}\right)$ akan berperan. Tidak ada kontraksi yang terjadi apabila pintu air terendam. Debit yang melalui pintu air berpengaruh tidak hanya pada kedalaman hulu untuk aliran bebas tetapi juga kedalaman aliran hulu dan hilir untuk aliran terendam pada pintu air. Pada debit yang terjadi, kedalaman aliran air pada hulu tidak tergantung pada kedalaman tailwater pada aliran bebas, tetapi akan meningkat bersama kedalaman tailwater ketika pintu air terendam (Kim 2007).

Dalam pintu air diperlukan ketelitian pada persamaan pintu untuk semua jenis aliran dan konfigurasi bukaan pintu. Perhitungan untuk menghitung koefisien kontraksi $\left(C_{c}\right)$ sudah banyak dilakukan hingga saat ini yang terjadi pada dasar saluran yang datar pada kondisi aliran bebas. Banyak konfigurasi bukaan pintu yang terjadi, dikarenakan dasar saluran yang tidak datar atau karena adanya perbedaan elevasi dari hulu ke hilir pintu atau karena pintu air yang terendam. Efek zat cair harus dipertimbangkan pada koefisien kontraksi. Kemungkinan pendekatan dengan menggunakan simulasi numerik dan kemudian diturunkan sehingga mudah digunakan. Percobaan dilakukan dengan dibatasi oleh konfigurasi aliran bebas dua dimensi, yang mencakup menghitung asumsi besaran yang biasanya digunakan untuk menerapkan teori potensial dan bagaimana pengaruhnya terhadap koefisien kontraksi dan koefisien debit (Cassan and Belaud 2008).

Kedalaman air di hulu pintu (headwater), bukaan pintu, dan kedalaman hilir pintu air (tailwater) merupakan parameter yang mengkategorikan klasifikasi aliran pintu air yaitu air bebas (modular) atau aliran terendam (non-modular) (Maatooq 2017). Aliran bebas zat cair yang mengalir pada bagian hilir terjadi karena perbandingan kedalaman hulu dengan tinggi bukaan pada pintu air dengan rasio yang relatif besar. Aliran yang terendam pada bagian hilir akan terjadi pada nilai rasio rendah. Untuk kondisi aliran bebas yang mengalir keluar dari pintu air umumnya karakteristik profil muka air akan rata atau halus, sedangkan untuk kondisi aliran terendam profil muka air akan kasar (Swamee 1992b).

\section{Material dan Metode}

\subsection{Keseimbangan Energi dan Momentum}

Debit yang mengalir pada pintu air dapat dihitung dengan Metode Energi dan Momentum (EM). Sketsa gambar pintu dapat dilihat pada Gambar 1, dengan bagian (a) kondisi aliran bebas dan (b) kondisi aliran terendam air. 


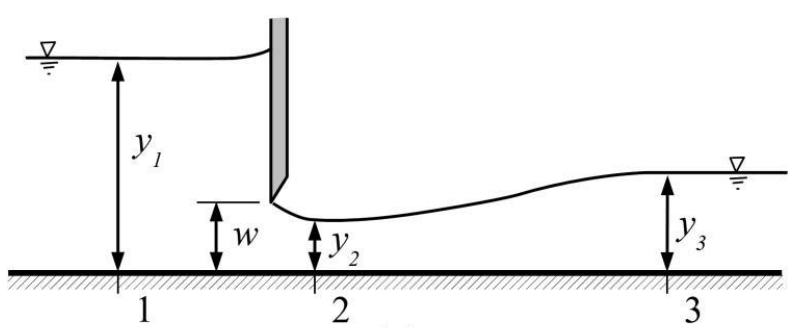

(a)

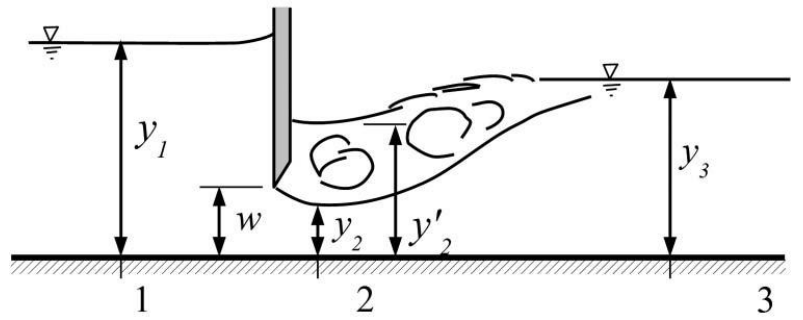

(b)

Gambar 1. Pintu Air:

(a) Aliran bebas; (b) Aliran terendam

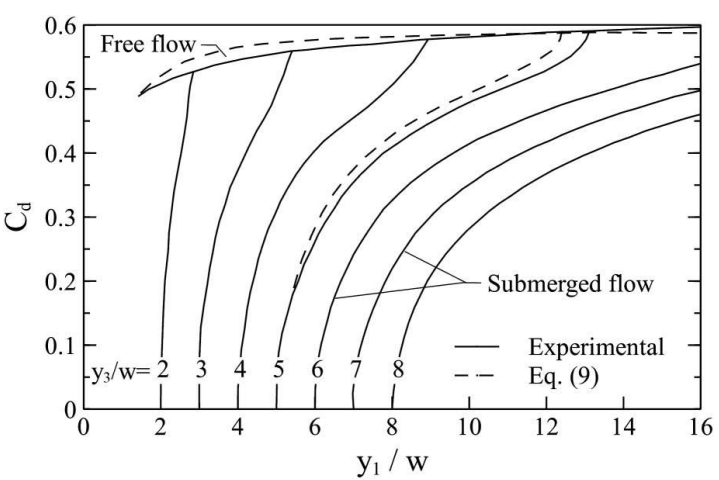

Gambar 2. Nomogram Henry (Silva and Rijo 2017)

Untuk aliran yang mengalir dibawah pintu (dengan asumsi tidak ada loncat air di hilir pintu) dan dengan menggunakan persamaan energi $\left(E_{1}=E_{2}\right)$, persamaan energi untuk saluran berbentuk persegi dapat ditulis dengan persamaan (1) dengan mengabaikan kehilangan energi antara bagian 1 dan bagian 2. Persamaan debit per satuan lebar dapat ditulis seperti pada persamaan (2). Sehingga kecepatan dapat ditulis seperti pada persamaan, dengan kecepatan yang terjadi seperti dalam persamaan (3). Persamaan (4) merupakan persamaan debit per satuan lebar untuk aliran bebas.

$$
\begin{gathered}
y_{1}+\frac{q^{2}}{2 g y_{1}^{2}}=y^{2}+\frac{q^{2}}{2 g y_{2} 2} \\
q=y_{1} y_{2} \sqrt{\frac{2 g}{y_{1}+y_{2}}} \\
v=\sqrt{2 g y_{1}}
\end{gathered}
$$

dengan $q=\frac{Q}{b}, Q$ merupakan debit yang terjadi ( $\mathrm{m}^{3} /$ detik), $b=$ lebar dari pintu air $(\mathrm{m}), g=$ percepatan gravitasi ( $\mathrm{m}^{2} /$ detik); $y_{1}=$ kedalaman air pada bagian hulu pintu; $y_{2}=$ kedalaman air pada vena kontrakta di bagian bawah pintu, $w$ = bukaan pintu $(\mathrm{m}), C_{d}=$ koefisien debit (coefficient of discharge). Untuk persamaan (2) dengan fungsi dari kecepatan $\sqrt{2 g y_{1}}$, debit untuk kondisi aliran bebas dapat dilihat dalam persamaan (4). 


$$
q=C c w \sqrt{2 g y_{1} \frac{y_{1}}{y_{1}+y_{2}}}=C d w \sqrt{2 g y_{1}}
$$

dengan $C_{c}$ merupakan koefisien kontraksi yang tergantung dari batas dari geometri dan hubungan dari $y_{2}$ dan $w$, yaitu $y_{2}=C_{c}$.w. Sehingga untuk koefisien debit dapat ditulis dalam persamaan (5)

$$
C d=\frac{C c}{\sqrt{1+C c\left(\frac{w}{y_{1}}\right)}}
$$

Koefisien berhubungan dengan bukaan pintu dan energi spesifik di bagian hulu pintu $\left(E_{l}\right)$ yang dapat dilihat dalam persamaan (6) (Yen, Lin, and Tsai 2001).

$$
E_{1}=\frac{Q^{2}}{2 g L^{2} y_{1}^{2}}
$$

Jika y3 yang merupakan loncat air (hydraulic jump) lebih besar dari $y_{2}$ yaitu aliran konjugasi, kondisi pada saat loncat air yang alirannya akan terendam dan pintu air akan tenggelam. Air yang mengalir melalui pintu air hanya memiliki kecepatan tranversal dan bersifat turbulen. Dalam analisis perkiraan, loncat air dapat dikategorikan sebagai aliran yang terbagi, dimana terdapat aliran yang bergerak dan aliran yang tergenang. Diantara bagian dari pintu air di bagian hulu dan hilir, terdapat kehilangan energi, yang biasanya diabaikan. Untuk kehilangan energi dari persamaan energi dapat dilihat seperti dalam persamaan (7).

$$
y_{1}+\frac{q^{2}}{2 g y_{1}^{2}}=y_{2}^{\prime}+\frac{q^{2}}{2 g y_{2}^{2}}
$$

Dengan kedalaman $y_{2}$ diubah dengan kedalaman piezometri yaitu $y_{2}{ }_{2}$. Diantara bagian 1 dan bagian 2 terdapat momentum dengan persamaan $M_{2}=M_{3}$, dan dapat ditulis dengan persamaan (8).

$$
\frac{q^{2}}{g y_{2}}+\frac{y_{2}^{\prime 2}}{2}=\frac{q^{2}}{g y_{3}}+\frac{y_{3}^{2}}{2}
$$

Menggunakan $y_{2}^{\prime}$ bukan $y_{2}$ pada bagian 2 . Sedangkan untuk $C_{d}$ pada aliran tenggelam seperti pada persamaan (9). Kedalaman maksimum ( $y_{3 \max }$ ), sehingga persamaan (9) merupakan persamaan untuk loncat air saat kondisi aliran bebas yang mengalir ke hilir pintu dari pintu air (Lin, Yen, and Tsai 2002).

$$
\begin{gathered}
C d=C c \frac{\left[\xi-\left(\frac{1}{\eta^{2}}\right)^{2}\left(\frac{1}{\lambda^{2}}\right)\right]^{\frac{1}{2}}}{\frac{1}{\eta}-\eta} \\
\left(y_{3}\right)_{\max }=C c b \frac{1}{2}\left[\sqrt{1+\frac{16}{\eta(1+\eta}-1}\right]
\end{gathered}
$$

Dengan, $\eta=\frac{C_{c} w}{y_{1}}, \xi=\left(\frac{1}{\eta}-1\right)^{2}+2(\lambda-1), \lambda=\frac{y_{1}}{y_{3}}$ 
Berdasarkan data percobaan yang dilakukan oleh Henry (1950) dalam Silva and Rijo (2017), sehingga dihasilkan lengkung $C_{d}=f\left(\frac{y_{1}}{w}\right)$ seperti pada Gambar 2, sehingga persamaan (11) merupakan persaamaan $\mathrm{C}_{\mathrm{d}}$.

$$
C_{d}=K C_{c} \sqrt{1-\frac{y_{2}}{y_{1}}}
$$

Dengan, $K=\frac{1}{\sqrt{1-\left(C_{c} w / y_{1}\right)^{2}}}$

Untuk aliran bebas persamaan (11) diterapkan secara langsung dan untuk aliran tenggelam $y_{2}$ harus diganti dengan $y_{2}^{\prime}$, sehingga menjadi persamaan (12).

$$
\frac{y_{2}^{\prime}}{C_{c} w}=\frac{K^{2} \sqrt{K^{4}+4 \Phi\left[\Phi\left(\frac{y_{3}}{w}\right)^{2}-\left(\frac{y_{1}}{w}\right) K^{2}\right]}}{2 \Phi}
$$

Dengan, $\Phi=\frac{1}{\left[4 C_{c}\left(1-\frac{\left(C_{c} w\right)}{y_{3}}\right)\right]}$, Silva and Rijo (2017) mengasumsikan nilai $C_{d}$ konstan yaitu sebesar 0.6.

Berdasarkan nomogram Henry yang dapat dilihat dalam Gambar 2, Swamee (1992) menunjukkan regresi tidak linear dan diperoleh persamaan (13) yang merupakan persamaaan debit untuk kondisi aliran normal dan dengan $y_{1} \geq 0.81 y_{3}\left(y_{3} / w\right)^{0.72}$.

$$
Q=0.611 w b \sqrt{2 g y_{1}}\left(\frac{y_{1}-w}{y_{1}+15 w}\right)^{0.072}
$$

Sedangkan untuk kondisi aliran terendam seperti pada persamaan (14), dengan $\left.\left.y_{3}<y_{1}<0.81 y_{3}\right) y_{3} / w\right)^{0.72}$.

$Q=0.611 w b \sqrt{2 g y_{1}}\left(\frac{y_{1}-w}{y_{1}+15 w}\right)^{0.072}\left(y_{1}-y_{3}\right)^{0.7}\left\{0.32\left[0.81 y_{3}\left(\frac{y^{3}}{w}\right)^{0.72}-y^{1}\right]^{0.7}\left(y_{1}-y_{3}\right)^{0.7}\right\}^{-1}$

Berdasarkan penelitian Rajaratnam dan Subramanya (1967) persamaan (14) merupakan persamaan untuk persamaan debit persatuan lebar yang pada umumnya digunakan, dengan menggunakan $C_{c}=$ 0.61 untuk lebih mudah penggunaan rumusnya. Untuk $\Delta y$ kondisi aliran bebas dapat dilihat dalam persamaan (16), sedangkan untuk kondisi aliran terendam persamaan (16) dapat digunakan, sedangkan untuk bagian transisi antara kondisi aliran bebas dan aliran terendam dapat digunakan persamaan (19) (Silva and Rijo 2017).

$$
q=C_{d} w \sqrt{2 g \Delta y}
$$

Pada saat kondisi aliran bebas maka

$$
\Delta y=y\left(y_{1}-C_{c} w\right)
$$

Sedangkan pada kondisi aliran terendam, 


$$
\begin{gathered}
\Delta y=\left(y_{1}-y_{2}^{\prime}\right) \\
\frac{y_{2}^{\prime}}{C_{d} w}=2\left(1-\frac{C_{d} w}{y_{3}}\right)+\left|4\left(1-\frac{C_{d} w}{y_{3}}\right)^{2}+\left(\frac{y_{3}}{C_{d} w}\right)-4\left(\frac{y_{1}}{C_{d} w}-\frac{y_{1}}{y_{3}}\right)\right| \\
\frac{y_{3}}{C_{d} w}=\frac{1}{2}\left(\sqrt{16 \frac{y_{1}}{C_{d} w}-15}-1\right)
\end{gathered}
$$

Sebagai alternatif, Clemmens, Strelkoff, and Replogle (2003) mengusulkan pendekatan yang dengan penelitian yang baru untuk mengevaluasi debit aliran yang melalui pintu radial yang berdasarkan Metode $E M$. Untuk aliran bebas persamaan di yang diusulkan merupakan persamaan yang mengabungkan koefisien kehilangan energi, $\xi$, untuk menggantikan distribusi kecepatan dari kontraksi jet dan kehilangan energi yang biasanya diabaikan. Persamaan (20) merupakan persamaan untuk menghitung debit air dalam kondisi aliran bebas, dengan $C_{c}$ merupakan fungsi dari $w / H_{1}$ untuk pintu air dan $H_{1}$ merupakan ketinggian energi. Persamaan (20) merupakan persamaan untuk kondisi aliran terendam beserta koreksi dari energi kinetic $\left(E_{\text {corr }}\right)$. Pada persamaan (21) membutuhkan perhitungan koreksi energi $E_{\text {corr }}$ dan perhitungan kedalaman $y^{\prime}$. . Untuk menghitung hubungan momentum antara bagian 2 dan 3 dapat menggunakan persamaan (22), dengan $v_{e}=$ kecepatan efektif pada jet, $v_{3}=$ kecepatan hilir, $F_{3}=$ gaya tekanan hidrostatik yang diberikan oleh kedalaman air pada bagian hilir, dan $F_{w}=$ komponen dari gaya permukaan air yang terjadi antara bagian 2 dan 3 searah dengan aliran air (termasuk gaya hidrostatis pada semua dinding) (Clemmens, Strelkoff, and Replogle 2003).

$$
\begin{gathered}
Q=C_{c} w b \sqrt{\frac{2 g\left(H_{1}-C_{c} w\right.}{1+\xi}} \\
Q=C_{c} w b \sqrt{\frac{2 g\left(H_{1}-y_{2}^{\prime}+E_{c o r r}\right)}{1+\xi}} \\
Q v_{e}+b g \frac{h_{2}^{\prime 2}}{2}+\frac{F_{w}}{\rho}=Q v_{3}+\frac{F_{3}}{\rho}
\end{gathered}
$$

Kehilangan energi pada pintu air diteliti oleh Habibzadeh, Vatankhah, and Rajaratnam (2011), mengemukakan mengenai kehilangan energi antara bagian 1 dan 2 yang biasanya diabaikan, dengan menunjukkan persamaan kehilangan energi $k V_{2}^{2} / 2 g$, dengan $\mathrm{V}_{2}$ merupakan kecepatan ratarata pada vena contracta. Persamaan (23) merupakan persamaan energi pada bagian 1 dan 2.

$$
y_{1}+\frac{q^{2}}{2 g y_{1}^{2}}=y_{2}+\frac{q^{2}}{2 g y_{2}^{2}}(1+k)
$$

Untuk aliran bebas $C_{d}$ subsitusi persamaan (4) dan persamaan (23), sehingga didapatkan persamaan (24).

$$
\begin{gathered}
C_{d}=C_{c} \sqrt{\frac{1-1 / \beta}{1+k-1 / \beta^{2}}} \\
\beta=\frac{y_{1}}{y_{2}}=\frac{y_{1}}{\left(C_{c} w\right)}
\end{gathered}
$$


Melalui perhitungan persamaan (23) dan persamaan (8), mengidentifikasi mengenai kemungkinan yang akan mengikuti $C_{d}$ pada kondisi aliran terendam seperti pada persamaan (26).

$$
\frac{C_{d}}{C_{c}}=\frac{\sqrt{[k \beta 2+(\beta-1) 2+2(\alpha-1)]}-\sqrt{\phi-\psi}}{\beta(1+k)-1 / \beta}
$$

Dengan, $\alpha=\frac{y_{1}}{y_{3}} ; \phi=\left[k \beta_{2}+(\beta-1)^{2}+2(\alpha-1)\right]^{2} ; \psi=\left[\beta^{2}(1+k)-1\right]^{2}\left(1-1 / \alpha^{2}\right)$

Persamaan (27) merupakan persamaan yang digunakan pada kondisi aliran transisi yaitu aliran diantara kondisi aliran bebas dan aliran terendam (Habibzadeh, Vatankhah, and Rajaratnam 2011).

$$
\frac{y_{3}}{w}=\frac{1}{2} C_{c}\left[\sqrt{1+\frac{16(\beta-1)}{1+k-1 / \beta^{2}}}-1\right]
$$

\subsection{Persamaan Debit Pada Aliran Melalui Orifice}

Dengan menggunakan pendekatan yang berbeda The Cemagref, membangun simulasi untuk saluran irigasi (Simulation of Irrigation Canals atau SIC), yang merupakan peranti lunak yang terdapat persamaan empiris debit untuk pintu air yang berdasarkan dari aliran yang melalui orifice. Untuk persamaan (28) merupakan persamaan pintu air pada kondisi aliran bebas ketika $y_{3} / y_{1} \leq \eta$.

$$
Q=b \sqrt{2 g}\left[C_{d F} y_{1}^{3 / 2}-C_{d 1}\left(y_{1}-w\right)^{3 / 2}\right]
$$

Untuk pintu air dalam kondisi aliran tenggelam, metode SIC memberikan dua kondisi yaitu kondisi aliran tenggelam sebagian dan kondisi aliran tenggelam penuh. Persamaan (29) untuk kondisi tenggelam sebagian akan sesuai dengan syarat $y_{3} / y_{1}>\eta$ dan $\left[y_{3} \leq \eta_{1} y_{1}+\left(1-\eta_{1}\right) w\right]$. Sedangkan persamaan (29) untuk kondisi aliran tenggelam penuh dapat dilihat dalam dan akan sesuai dengan syarat $y_{3} / y_{1}>\eta$ dan $\left[y_{3}>\eta_{1} y_{1}+\left(1-\eta_{1}\right) w\right]$.

$$
\begin{gathered}
Q=b \sqrt{2 g}\left[k_{F} C_{d F} y_{1}^{3 / 2}-C_{d 1}\left(y_{1}-w\right)^{3 / 2}\right] \\
Q=b \sqrt{2 g}\left[k_{F} C_{d F} y_{1}^{3 / 2}-k_{F} C_{d 1}\left(y_{1}-w\right)^{3 / 2}\right]
\end{gathered}
$$

dengan; $\eta=1-0,14 y_{3} / w ; \eta_{1}=1-0.14\left(y_{3}-w\right) / w$ dengan syarat diantara $(0.40-0.75) ; \mathrm{C}_{\mathrm{dF}}=$ $\mathrm{C}_{\mathrm{d} 0}-0.08 /\left(\mathrm{y}_{1} / \mathrm{w}\right) ; \mathrm{C}_{\mathrm{d} 1}=\mathrm{C}_{\mathrm{d} 0}-0.08 /\left[\mathrm{y}_{1} /(\mathrm{w}-1)\right]$.

$$
\begin{gathered}
K_{F}=\left\{\begin{array}{c}
1-(1-x / \sqrt{1-\eta})^{\beta} \\
5 x\left[1-(1-0.2 / \sqrt{1-\eta})^{\beta}\right]
\end{array}\right\} \\
K_{F 1}=\left\{\begin{array}{c}
1-\left(1-x_{1} / \sqrt{1-\eta_{1}}\right)^{\beta_{1}} \\
5 x\left[1-(1-0.2 / \sqrt{1-\eta 1})^{\beta_{1}}\right]
\end{array}\right\}
\end{gathered}
$$

dengan $x=\sqrt{1=y_{3} / y_{1}} ; \beta=-2 \eta+2.6 ; \beta_{1}=-2 \eta_{1}+2.6 ; x_{1}=\sqrt{1-\left(y_{3}-w\right) /\left(y_{1}-w\right)}$

Sedangkan nilai $C_{d 0}$ merupakan satu-satunya parameter yang ditentukan dengan kalkulus oleh peneliti, yang merupakan fungsi dari $C_{d}$, ditentukan dari $C_{d 0}=2 / 3 C_{d}$. Umumnya menggunakan 0.6 atau ditentukan dari nilai percobaan.

US. Army Corps of Engineers' River Analysis System (HEC-RAS) merupakan peranti lunak yang dapat menunjukkan simulasi satu dimensi pada aliran steady dan unsteady untuk aliran hidraulikaa pada sungai. Untuk analisis pintu air berdasarkan $H E C-R A S$ seperti pada persamaan (4) untuk 
kondisi aliran bebas dengan syarat $y_{3} / y_{1} \leq 0.67$; untuk kondisi aliran terendam dengan syarat $0.67<y_{3} / y_{1}<0.80$ sebagian dapat menggunakan persamaan (32), sedangkan persamaan (34) untuk kondisi aliran terendam penuh dengan syarat $y_{3} / y_{1} \geq 0.80$. Nilai variabel $C_{d}$ dan $C^{\prime}{ }_{d}$ merupakan nilai pilihan kalibrasi konstan yang digunakan, umumnya antara 0.5 - 0.7 (HEC-RAS 2016).

$$
\begin{aligned}
& Q=C_{d} b_{w} \sqrt{2 g_{3}\left(y 1-y_{3}\right)} \\
& Q=C^{\prime}{ }_{d} b_{w} \sqrt{2 g_{3}\left(y 1-y_{3}\right)}
\end{aligned}
$$

\section{Hasil dan Pembahasan}

\subsection{Maksimum Bukaan Pintu}

Kondisi aliran bebas yang mengalir di bawah pintu air, aliran air di bagian hulu pintu merupakan aliran sub kritis (subcritical) sedangkan aliran air yang mengalir di hilir pintu merupakan aliran super kritis (supercritical). Ketika bukaan pintu air sama dengan atau lebih dari kedalaman air kritis $(y c)$, tidak akan ada loncat air yang terjadi dan kondisi aliran air yang tidak akan ada. Pada kondisi tersebut pintu air tidak akan bisa mengatur aliran, dan akan menyebabkan beberapa kondisi permukaan air akan mengalami gangguan. Persamaan (35) dan (36) merupakan persamaan kedalaman kritis (Yen, Lin, and Tsai 2001).

$$
\begin{gathered}
y_{c}=\left(\frac{Q^{2}}{g L^{2}}\right)^{\frac{1}{3}} \\
y_{c}=\left(\frac{2 C_{c}^{2} w^{2} y_{1}}{1+\frac{C_{c} b}{y_{1}}}\right)^{\frac{1}{3}}
\end{gathered}
$$

Kedalaman kritis dapat dianggap sebagai maksimum bukaan pintu air yang dapat dikontrol untuk aliran bebas $\left(w_{\max }\right)$ dapat dilihat dalam persamaan (36) subsitusikan ke persamaan (37) sehingga didapatkan persamaan (38) untuk mendapatkan nilai dari $w_{\max }$.

$$
\begin{gathered}
\frac{C_{c} w_{\max }}{y_{1}}+\left(\frac{C_{c} w_{\max }}{y_{1}}\right)^{2}=2 C_{c}^{3} \\
\frac{y_{1}}{w_{\max }}=\frac{2 C_{c}}{-1+\sqrt{1+8 C_{c}^{3}}}
\end{gathered}
$$

Persamaan (39) dan (40) merupakan persamaan untuk menentukan nilai maksimum angka Froude pada bagian hulu pintu $\left(F_{1}\right)$ dan nilai minimum angka Froude pada bagian hilir pintu $\left(F_{2}\right)$.

$$
\begin{gathered}
F_{1 \max }=\left(-1+\sqrt{\left.1+8 C_{c}^{3}\right)} x\left(1+\sqrt{1+8 C_{c}^{3}-\frac{1}{2}}\right.\right. \\
\left(F_{2}\right)_{\min }=C_{c}^{-\frac{3}{2}}
\end{gathered}
$$

dengan $C_{c}$ adalah 0.61 yang didapatkan dari $w_{\max }=0.556 y_{1}, y_{1} / C_{c} w_{\max }=2.95,\left(F_{1}\right)_{\max }=0.414$ dan $\left(F_{2}\right)_{\min }=2.099$.

Hasil percobaan dan perhitungan dari aliran yang melalui pintu air dengan aliran bebas dengan rasio kedalaman muka air di hulu pintu air dan ketinggian bukaan pintu dengan menggunakan persamaan Reynolds averaged Navier Stokes berada pada kisaran 4-16. Perhitungan profil aliran 
dan distribusi tekanan dibandingkan dengan hasil percobaan merupakan metode sejauh ini merupakan metode terbaik (B. Xu and Samuel Li 2020; X. L. Xu et al. 2009).

\subsection{Koefisien Kontraksi}

Teori aliran potensial menyebabkan analisis yang menentukan $C_{c}$ pada aliran bebas, berdasarkan dari pemetaan antara bidang fisik dan bidang potensial komplek. Pengamatan koefisien kontraksi pada pintu air pada saluran datar pada kondisi saluran bebas dan terendam berdasarkan persamaan konservasi momentum, berdasarkan dari determinasi aliran dari tekanan yang diterima pada pintu air bersama-sama dengan persamaan energi. Dengan menggunakan metode numerik, efek dari bukaan pintu $(w)$ pada $C_{c}$ pada aliran potensial sudah banyak dilakukan dengan peningkatan penentuan permukaan bebas dalam aliran bebas, yang telah dilakukan saat kondisi terendam. Kurangnya latar belakang teoritis, asumsi umum saat $C_{c}$ sama dengan $C_{c}$ aliran terendam pada aliran bebas. Rajaratnam dan Subramanya dalam (Gilles Belaud, Cassan, and Baume 2009) melakukan analisis yang detail struktur aliran dibawah pintu air yang terendam hingga $w=h_{0} / 10$, dimana $h_{0}$ merupakan kedalaman air di hulu pintu. Penelitian menunjukkan kesulitan untuk menentukan bagian mana yang berkontraksi yang dihubungkan pada aliran terendam tetapi dengan mengajukan definisi yang jelas dari kedalaman aliran yang mengalami kontraksi berdasarkan pada konservasi massa. Teori pendekatan berdasarkan konservasi energi dan momentum, serta penggambaran pengusulan yang dikembangkan pada hulu pintu air. Metode tersebut mengarah pada analisis penentuan $C_{c}$, keduanya pada aliran bebas dan aliran terendam dan kemudian melakukan pengamatan pada koefisien debit $\left(C_{d}\right)$. Dalam percobaan ini mengusulkan teori baru untuk perhitungan koefisien kontraksi untuk aliran di bawah pintu air pada saluran datar. Pendekatan berdasarkan konservasi energi dan momentum diantara bagian hulu pintu dan bagian kontraksi, bergantung pada analisis perhitungan tekanan pada hulu pintu air. Pada kondisi aliran terendam dengan teori pendekatan yang tersedia. Pada bagian yang terendam sebagian merupakan vena contracta yang tenggelam tetapi pada terdapat air yang berada di bagian hilir air tidak menyentuh bagian sisi bawah dari pintu air. Pada aliran terendam, nilai $C c$ hampir sama dengan nilai pada aliran bebas, ketika bukaan pintu kecil dan terendam, yang diperkuat dengan hasil penelitian dan secara umum asumsi diterima. Hal ini tidak akan berlaku pada bukaan besar, dimana $C c$ lebih besar dari 0,6 dan aliran air dalam kondisi sepenuhnya tenggelam. Variasi $C c$ menjadi salah satu parameter yang dipertimbangakan untuk menghitung aliran yang melalui pintu air yang terbuka besar dan pintu air yang terendam, untuk tujuan pembuatan model dan pengukuran (Gilles Belaud, Cassan, and Baume 2009).

Ludovic Cassan and Belaud (2012) mempelajari secara eksperimental dan numerik mengenai karakteristik aliran pada hulu dan hilir pintu air menggunakan Reynolds Averaged Navier-Stokes simulasi dua dimensi dengan volume dari metode fluida. Fokus pengamatan pada bukaan pintu air yang dibuka lebar dan pintu air terendam. Hasil penelitian diperoleh dengan menggunakan pengukuran Acoustic Doppler Velocimeter (ADV) yang memperoleh distribusi kecepatan rata-rata yang terjadi dan karakteristik aliran turbulen. Kecepatan bidang disimulasikan menggunakan model turbulensi Re-Normalization Group (RNG) $k-\varepsilon$ dan Model Tegangan Reynolds, yang mengarah pada perhitungan energi dan koefisien koreksi momentum, kehilangan energi dan gaya gesek yang disebabkan oleh dasar saluran. Koefisien kontraksi juga terbukti akan bertambah dengan meningkatnya bukaan pintu pada aliran terendam yang besar, yang mana hal tersebut konsisten dengan keseimbangan energi-momentum (energy momentum balance-EMB). Pemilihan model turbulen sangat penting sebagai standar model $k-\varepsilon$ dan $k-\omega$ yang lebih besar daripada perkiraan kontraksi ketebalan aliran. Dengan Root Mean Square (RSM) dan $R N G k$ - $\varepsilon$, profil kecepatan dihitung akurat. Profil kecepatan kemudian dapat digunakan untuk memperkirakan koefisien energi dan momentum, kehilangan energi, gaya gesek dan koefisien kontraksi. Seperti koefisien yang digunakan untuk mengukur keseimbangan energi dan momentum. Pada aliran terendam dengan bukaan pintu yang besar, $C c$ seharusnya tidak dipertimbangkan untuk aliran bebas pada pintu air (dengan koefisien 0.61) karena hal tersebut telah diverifikasi untuk bukaan pintu yang diperbesar. Keseimbangan energi dan momentum merupakan metode yang digunakan untuk variasi dan perhitungan ketelitian dari koefisien debit (Ludovic Cassan and Belaud 2012). 
Kim (2007) mempelajari mengenai analisis dari aliran bebas melalui pintu air. Penelitian menunjukkan bahwa persamaan numerik dengan menggunakan persamaan Reynolds Averaging Navier Stokes (RANS) cukup dapat digunakan untuk menghitung koefisien kontraksi dan koefisien debit, dan distribusi tekanan untuk aliran bebas melalui pintu air. Tidak ada asumsi dalam menentukan geometri pemukaan air bebas, aliran fluida yang sebenarnya, dan gravitasi. Pada umumnya, percobaan koefisien kontraksi lebih besar dari perhitungan yang dihasilkan oleh teori aliran potensial. Kencenderungan tidak terlihat dari teori koefisien kontraksi cukup berbeda dari antara keadaan sebenarnya di lapangan dan dari percobaan. Pada saat bukaan pintu berangsurangsur naik, koefisien kontraksi pada penelitian ini berangsur-angsur menurun jika rata-rata bukaan pintu $\left(a / E_{1}\right)$ kurang dari 0.4 dan naik jika rata-rata bukaan pintu lebih besar dari 0.4 yang menunjukkan kencenderungan yang sama dengan data percobaan. Hal ini dikarenakan kehilangan energi akibat gesekan dan gerakan permukaan air meningkat dikarenakan pendekatan kecepatan dari kenaikan bukaan pintu hingga bukaan pintu lebih besar daripada 0.4. Koefisien debit dan distribusi tekanan dari analisis hasil penelitian berhubungan dengan hasil percobaan penelitian. Koefisien debit dari hasil percobaan didapat nilai sebesar 0.506 hingga 0.598. Distribusi tekanan sepanjang dasar saluran dan pintu air juga diperhitungkan dan kinerja analisis numerik yang tidak digunakan pada pengasumsian diterapkan pada teori aliran potensial yang terjadi, koefisien kontraksi, koefisien debit, dan distribusi tekanan dianalisis secara menyeluruh (Kim 2007).

Fenomena hidraulika untuk pendekatan membedakan aliran dibawah pintu air yang dilakukan di laboratorium. Penelitian ini mempelajari mengenai persamaan yang diusulkan yang berhubungan dengan pertimbangan fenomena hidraulika yang disebut vena contracta disamping dengan hubungan antara elevasi muka air di hulu dan hilir pintu air. Penelitian dilakukan dengan mengumpulkan 54 data untuk aliran bebas dan aliran terendam, data termasuk dengan perbedaan debit, bukaan pintu kedalaman air pada hulu pintu beserta kedalaman air pada tailwater dan kontraksi pada bagian hulu. Untuk membedakan kondisi aliran yang mengalir di pintu air tersebut merupakan aliran bebas atau terendam dengan mengindikasi ketergantungan hidraulika antara headwater, tailwater dan bukaan pintu, yang akan mempengaruhi debit yang melalui pintu air. Demikian juga, untuk kondisi aliran tertentu pada saat kedalaman hulu mengalami peningkatan ketika kondisi aliran di hilir terendam. Aliran terendam terjadi ketika loncat air (hydraulic jump) berada dibawah pintu air dan terendam bersama-sama dengan tailwater. Kondisi yang membedakan ditemukan untuk memperkuat fungsi dari koefisien kontraksi. Dalam karakteristik dan parameter hidraulika, koefisien debit merupakan parameter yang paling penting dalam perhitungan debit. Karena terdapat lapisan batas yang terjadi dan kehilangan energi pada hulu pintu air nilai dari penelitian koefisien kontraksi akan lebih tinggi (Maatooq 2017).

Hubungan antara pintu air terendam $(C c=0.61)$ dan pintu air yang terbuka penuh $(C c=1)$, pintu air terendam mempunyai batasan angka untuk meneliti mengenai percobaan dan memiliki validasi yang sangat detail, banyak fenomena yang dihitung seperti distribusi pada pintu air, pengukuran hilir pintu air. Pengukuran dilakukan dengan menggunakan Acoustic Doppler velocimetry pada lokasi penelitian, dengan menggunakan computational fluid dynamic (CFD) untuk menginterpolasi karakteristik aliran antara titik pengukuran dan konfigurasi penelitian yang percobaan tersebut. Verifikasi dari penelitian menggunakan analisis hasil numerik berdasarkan simulasi Reynolds Navier Stokes dengan metode volume air dan model tegangan Reynolds sebagai model yang mendekati (G. Belaud, Cassan, and Baume 2014).

\section{Kesimpulan}

Karakteristik aliran yang mengalir melalui pintu air dapat diketahui melalui hubungan dari persamaan dasar keseimbangan energi dan momentum. Persamaan debit dapat dicari dengan vena contracta yang merupakan fenomena hidraulika pada pendekatan aliran melalui pintu air menghasilkan nilai koefisien debit $(C d)$ dan koefisien kontraksi $(C c)$. Fenomena rasio perhitungan didapatkan dari beberapa metode yang ada, rasio pengukuran, perhitungan kejadian secara teoritis dan melalui percobaan di laboratorium. Persamaan debit tidak akan efektif bila digunakan pada kondisi bukaan pintu yang besar dan pada kondisi pintu terendam penuh. Variasi $C c$ menjadi salah satu parameter yang dipertimbangkan untuk menghitung aliran melalui pintu air. Pada aliran terendam dengan bukaan pintu yang paling besar, $C c$ tidak dipertimbangkan karena akan menjadi 
aliran terendam pada pintu air (dengan koefisien 0.61). Penelitian lebih lanjut diperlukan untuk lebih mengetahui secara detail mengenai aliran yang mengalir dibawah pintu air, baik sebagai aliran bebas dan aliran terendam. Penelitian di laboratorium dengan membuat model sesuai dengan yang diinginkan dengan kondisi sesuai pemodelan pintu air aliran bebas dan aliran terendam atau dengan prototipe dari kondisi sebenarnya di lapangan beserta efek skala yang mengikutinya. Bantuan peralatan seperti salah satu contoh yaitu DLDV (Discriminator Laser Doppler Velocimetry) Analisis secara numerik dan analisis dengan menggunakan bantuan piranti lunak sehingga dapat menjadi perbandingan. Rasio perbandingan yang didapatkan dapat menjadi salah satu acuan untuk penelitian yang digunakan, sehingga didapatkan nilai kecepatan aliran, distibusi kecepatan dengan rasio perbandingan yang seminim mungkin.

\section{NOTASI:}

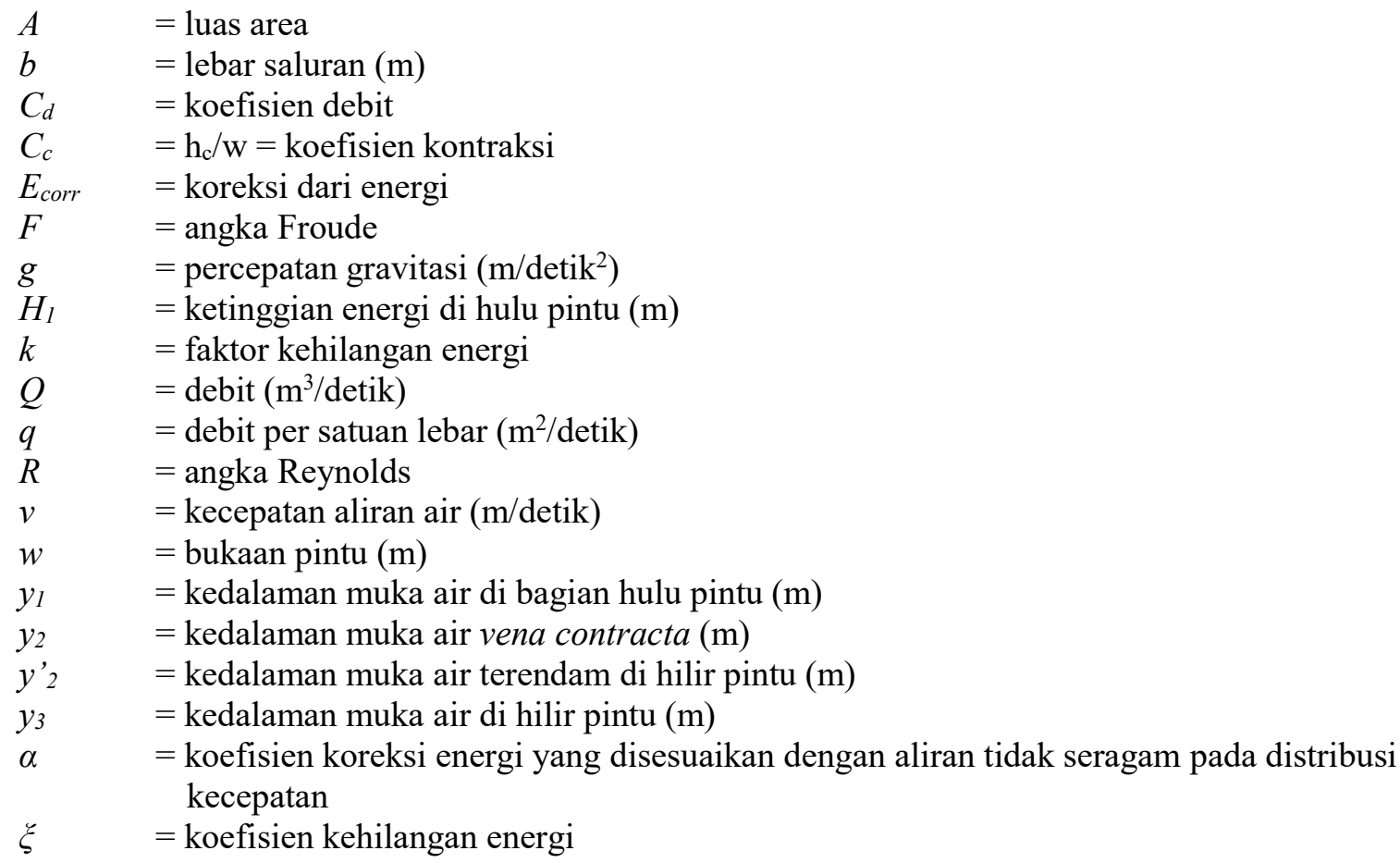

\section{Daftar Pustaka}

Belaud, G., L. Cassan, and J. P. Baume. 2014. "Discussion of 'Revisiting the Energy-Momentum Method for Rating Vertical Sluice Gates under Submerged Flow Conditions' by Oscar Castro-Orgaz, Luciano Mateos, and Subhasish Dey." Journal of Irrigation and Drainage Engineering 140(7).

Belaud, Gilles, Ludovic Cassan, and Jean Pierre Baume. 2009. "Calculation of Contraction Coefficient under Sluice Gates and Application to Discharge Measurement." Journal of Hydraulic Engineering.

Cassan, L., and G. Belaud. 2008. "RANS Simulation of the Flow Generated by Sluice Gates." Hydraulic Structures: 217-25.

Cassan, Ludovic, and Gilles Belaud. 2012. "Experimental and Numerical Investigation of Flow under Sluice Gates." Journal of Hydraulic Engineering 138(4): 367-73.

Clemmens, A. J., T. S. Strelkoff, and J. A. Replogle. 2003. "Calibration of Submerged Radial Gates." Journal of Hydraulic Engineering 129(9): 680-87.

Habibzadeh, A., Ali R. Vatankhah, and N. Rajaratnam. 2011. "Role of Energy Loss on Discharge Characteristics of Sluice Gates." Journal of Hydraulic Engineering 137(9): 1079-84.

HEC-RAS. 2016. "Hydraulic Reference Manual Version 5.0." (February): 547. 
Kim, Dae-Geun. 2007. "Numerical Analysis of Free Flow Past a Sluice Gate." KSCE Journal of Civil Engineering 11(2): 127-32.

Lin, C. H., J. F. Yen, and C. T. Tsai. 2002. "Influence of Sluice Gate Contraction Coefficient on Distinguishing Condition." Journal of Irrigation and Drainage Engineering 128(4): 249-52.

Maatooq, Jaafar. 2017a. "Hydraulic Characteristics and Discharge of Canal Sluice Gate : Practical Approach.” (November 2016).

. 2017b. "Hydraulic Characteristics and Discharge of Canal Sluice Gate : Practical Approach Hydraulic Characteristics and Discharge of Canal Sluice Gate : Practical Approach.” (November 2016).

Silva, Carlos Otero, and Manuel Rijo. 2017. "Flow Rate Measurements under Sluice Gates." Journal of Irrigation and Drainage Engineering 143(6): 2016.

Swamee, Prabhata K. 1992a. "Sluice-Gate Discharge Equations." Journal of Irrigation and Drainage Engineering 118(1): 56-60.

Swamee, Prabhata K. 1992b. "Sluice Gate Discharge Equation." ASCE J. Irrig. Drain. Div. 118(3): 480-96.

Xu, Bowen, and S. Samuel Li. 2020. "Underflow Curvature and Resultant Force on a Vertical Sluice Gate." Journal of Hydraulic Engineering 146(4): 1-10.

Xu, Xian Li et al. 2009. "Runoff and Water Erosion on Road Side-Slopes: Effects of Rainfall Characteristics and Slope Length." Transportation Research Part D: Transport and Environment 14(7): 497-501.

Yen, Jung Fu, Chih Han Lin, and Chang Tai Tsai. 2001. "Hydraulic Characteristics and Discharge Control of Sluice Gates." Journal of the Chinese Institute of Engineers, Transactions of the Chinese Institute of Engineers, Series A/Chung-kuo Kung Ch'eng Hsuch K'an 24(3): 301-10. 